\title{
memory palace
}

\author{
Rita Wong

\section{palais de la mémoire}

Dans les courts poèmes réunis sous ce titre, Rita Wong évoque l'une après l'autre les différentes pièeces de la maison, autant de composantes $d u$ palais de la mémoire. Ses visions syncrétiques de l'univers du quotidien dinstinguent la chambre des rêves, le corridor de l'étage et la pièce des bains de vapeur, puis le corridor du bas, la cuisine et la porte, en des termes qui font converger la dépense, la fatigue et l'usure du corps, puis le confort du lit. S'y trouve inscrit en filigrane le travail féminin, souvent invisible.

Phrases sensuelles et riches où la couleur et les formes s'unissent dans des descriptions d'une matière inondée de lumière: Qui a lavéles draps? Fait le lit? (...) Bleu royal, pourpre, dessins au crayon violet sur le mur. Une maison à l'intérieur d'une maison, à l'intérieur d'une maison. (...). Vous croyez avoir bien fermé les portes et maintenant le vent les ouvre toutes grandes. (...) Lavande, sel de mer (...) chaleur de la peau fraîche qui exulte. (...) Seuls subsistent quelques photos, des fantomes plats : travaux non payés dans le jardin, mains brunes, noueuses, calleuses tenant un balai (...).

: dream chamber

sleepy red moments, the haze of morning lingers in the daily promise of beginnings from the warm tangle of black hair and heavy limbs resting from nightly travels and unspun desire flannel comfort, pillowy half-thoughts wander over the threshold: who washed the sheets? who made the bed? scarves hang, silk unravels

: upstairs hallway 
royal blue, crimson, violet crayon sketches on the wall a house within a house within a house stick figures dance childhood scenarios memory hopscotches on the hardwood floor daylight plays tricks:

once you sang the hieroglyphs in the rug, once you drew the doors shut tight \& now the wind blows them open

: steamy chamber

lavender, sea salt, traces of home bubbling rebirth, domestic ritual: washing of hands, squeezing of hair endless cleansing the way we survive urban grime, cold subway underbellies reborn as flesh in the bodily waters, warmth of fresh skin sings alive

: downstairs hallway

flicker with the shadows of nightlight creatures knock-echo against closed doors even a simple trip to the bathroom and its cold floors raises visions of skeletons, interior monsters, bony anger, warped and knotted like ivory driftwood gathered from the beached languages lost from our tongues, words we no longer have, replaced by ones we no longer want endless doors opening from this central line into shaded hunger, half-voiced hope to someday read the black strokes, taste the nourishment of many tones to flavour bland white sentences, let chaos filter the split between complete and incomplete, bleed the two into one sharp fruit 
: kitchen

the centre of unpaid work, preparation for devouring mouths spicy wok, dependable rice cooker, endless chopping into digestible morsels,

endless pieces of noodle swirl, garlic ginger traces resting on the lightness of breath,

the exhale of pungent works leading into story, gossip feeding us, crunchysweet as carrots

\section{: doorway}

so many, the wider the better,

the broad open space of living room, really every room should be for living,

its conjunction of dining space, border personified, corresponding windows look over the street, ogle bystanders, giggle, whisper

of forgotten aunts, thin slanted women drowned out by the grandfather clock chimes,

all that is left are a few photographs, flat ghosts: unpaid digging, planting, watering in the garden, brown, wiry callused hands holding a broom, bristle against the grainy remnants of the day's travails 